\title{
LOGISTICS CENTRES OF EASTERN POLAND IN THE PAN-EUROPEAN TRANSPORT CORRIDOR NO. 2
}

DATA PRZESŁANIA: 24.05.2016 | DATA AKCEPTACJI: 5.07.2016| KOD JEL: R41

\section{Bartosz Zakrzewski}

Motor Transport Institute, Warsaw

e-mail: bartosz.zakrzewski@its.waw.pl

\section{INTRODUCTION}

The rapid development of modern logistics centres is associated with the increasing differentiation of component services, storage, handling, distribution and others in transport hubs. There are often transit hubs where, for example, a change in the means of transport or bringing about various operations on the load is carried out (e.g. refinement, repackaging, consolidation and distribution shipments). Transport hubs and logistics centres located in large settlement units usually are of a transit nature, such as lying on the routes, and at the same time are the starting or the final point for specific routes. They must be suitably and technically equipped (Kuśmińska-Fijałkowska, Łukasik, 2015, pp. 131-138) and efficiently managed in an increasingly complex social and economic reality (Brdulak, Zakrzewski, 2013).

It is not always the case, however, that transport hubs are functionally related to the large settlement units. An example of this could be the Polish inland railway stations located on the eastern 
border, which were formed at the junction of railway lines with a different gauge and their transit services were supplemented over time by the offer of other modes of transport (mainly motor vehicles) as well as forwarding and logistics services. Moving the customs border of the European Union on the line of the Bug River and the appearance of foreign investors in these previously "monoculture" rail transit hubs have created new development opportunities in recent years, especially on the eastern section of the Pan-European Transport Corridor No. 2 belt running through Poland.

The aim of this article is to characterize the logistics centres and their potential on the example of the Polish eastern transport corridor No. 2 belt. Analysis of the nature and functions of the logistics centre will lead to derive the authorss own definition of a logistics centre. Location issues of potential logistics centres in eastern Poland will also be analyzed and compared with similar investments in the Belarusian part of the international transport corridor No. 2. Reference analysis and long-term studies of ITS in eastern Poland has enabled the preparation of the characteristics of the logistics potential of eastern Poland.

\section{LOGISTIC CENTRES - DEFINITION}

The technical infrastructure of transport - creating a network of roads and transport points - often takes the shape of spatial transport hubs in its focus. The prerequisites for a transport infrastructure logistics network are the backbone for the flow of the supply chain. Thus, the functional hubs are transportation and logistics hubs and by frequently complementing the service offer at the hub points help organizations of all passengers and goods flows providing them with significant concentrations of activity in the TSL (Transport-Shipping-Logistics) sector (Brdulak, Zakrzewski, 2013; Fechner, Szyszka, 2006). The network flow of goods, handling, separating or combining loads, changing operators and distributors, cross docking stations, freight handling terminals, warehouse and storage facilities in the ports must find their place in appropriately equipped points in the network infrastructure. Logistic centres are primarily the strategic dimension of these.

Defining logistics centres encounters some difficulties in the literature. Professor Beata Skowron-Grabowska draws attention to them (Skowron-Grabowska, 2010): “(..) definitions of a logistics centre appearing in the literature vary. Most stress the importance of the logistics centre as an organization including such terms as an economic entity, facility, centre, place or main element. Other definitions however emphasize the functional approach, thus indicating to the second aspect of the logistics centre. Their example is to show the activity, involving the realization of the rapid movement of goods or the integration of different transport modes. The definitions of these also highlight the international character of logistics centres (...). It can therefore indicate the evolution of logistics centres, which in the first periods of operation focused on a small number of service-type storage and transport. Logistics centres offered a wider package of services with their development (...)". Therefore, in practice, an average economically developed country such as Poland, has complete freedom interpreting the concept of "logistics centre". We come across naming in very few, comprehensive cases with entities separated organizationally, technically and legally and locations of TSL sector activity, as well as in individual cases of single roadside stores of one mode of transport.

In this respect, it is proposed to adopt the definition of B. Skowron-Grabowska in the studies devoted to the communications corridor, according to which "(...) a logistics centre is an economic entity of an interregional and/or international nature, coordinating comprehensive logistics 
services, equipped with adequate transport, storage and information technology infrastructure as well as being necessary to carry out staff and organization tasks" (Skowron-Grabowska, 2010). This approach is consistent with the system's reorganization of the elements of the actual functioning of broadly understood transport. Then it would be necessary to understand that „a logistics centres remains a collection of organizational and legal, technical, economical and spatial structure due to the state of the transport infrastructure - they are social and economic process entities that co-contribute in a coordinated manner in order to meet the complex needs of logistics within specific supply chains” (Banak, Brdulak, Krysiuk, Pawlak, 2014; Brdulak 1989).

The conceptual diversity associated with logistics centres also results in extensive typology. We can mention/change centres accordingly depending on:

1. The scope of functions, such as:

- integrated centres offering many services, including combined freight handling,

- logistic villages grouping producers and distributors in its area, in addition to logistics companies and distributors,

- distribution centres,

- warehouse storage centres,

- transport terminals, exclusively providing transport services;

2. The scale of impact:

- centres of international significance, centres of regional significance, centres of local significance;

3. Supported operational range:

- centres of universal support of different types of goods, centres of industry being limited to specialized product groups of goods;

4. Spatial position:

- focus centres engaged in a defined territory and possessing a specific logistics infrastructure, centres which are virtual, dispersed, internet-operating in cyberspace on an electronic platform, bringing together logistics providers and companies offering complementary services in the selected region;

5. Branch supported transport:

- warehouse and storage centres, components of land transport in particular road vehicles,

- sea ports, railway stations, airports, inland river ports.

It is indicated that in modern, comprehensive logistics centres (Brdulak, Zakrzewski, 2008, pp. 26-37; Paprocki, 2003):

- the service recipient has access to at least two branches of (types of) transport,

- techniques are used for handling freight on conventional transport and combined transport,

- freight handling operations going beyond transshipment operations,

- economic entities carrying out cargo handling activities involved in integrated logistics solutions.

To sum up, a logistics centre, in the full sense of the word, should implement a wide range of tasks such as (Zakrzewski, 2008, pp. 14-16; Zakrzewski, 2008, pp. 21-24):

- organization and coordination of freight, also on an international scale,

- associating various branches/modes of transport and the organization of their interoperability, 
- sharing their own logistics infrastructure and creating conditions for the operation of logistics operators and companies with the business environment,

- bringing together the supply and demand for logistics services,

- creating conditions for the growth of value-added logistics services,

- creating an area for fair competition and free market pricing for logistics services on a local, regional and international scale.

Despite its efforts, Poland has not developed a real policy for the construction and location of logistics centres up to now. Today, it is a grassroots initiative and is the responsibility of mostly foreign businesses and corporations which, after the economic calculation, decide to locate such a storage centre in a certain place in consultation with local authorities. In the meantime, since Poland's accession to the European Union, the eastern part of Poland which lies in II Pan-European transport corridor impact zone has an excellent, well developed transportation infrastructure in place for the location of a modern logistics centre.

\section{EASTERN POLAND AND THE LOCATION OF LOGISTICS CENTRES}

A logistics centre, by definition, is established in regions that generate large flows of freight cargo, including coordinating the work of various modes of transport. This means the inclusion of activities in the transport of all resources that are necessary to ensure its success, i.e. satisfying the needs of transport. In addition, in its activities, a logistics centre controls transportation processes through proper organization and coordination affecting the development of the transport industry and the types of transport in the region. It affects the shape, quality and number of operators, freight forwarders, freight handlers, transportation, linear infrastructure, focal and technical infrastructure as well as freight, warehouse and technical facilities. Thus, with proper cooperation with regional authorities, planning and supply can be controlled and can have a large impact on the shape and harmonious development of the transport system in eastern Poland, in the impact zone of the Pan-European Transport Corridor No. 2.

According to the issue, the problem remains to determine whether the eastern Poland Pan-European Transport Corridor No. 2 impact zone has a chance to develop comprehensive logistics centres in the near future. The considerations omit prolonged adverse conditions or outright political disaster. The assumption of their further, long-term occurrence undermines all prerequisites for international economic cooperation in Europe. With this it poses the thesis that this process is possible and economically purposeful.

The nearest establishment of an extended logistics centre of international importance is the border zone between the town of Biała Podlaska and Małaszewicze-Terespol. In a large part, this is a great, "dry" port station area of Małaszewicze where wide railway tracks "run" for 30 kilometers into the territory of the country, allowing the transshipment of goods from/ to the European rolling stock fleet. Despite the commercial difficulties of a political nature of reloading at the border railway station, it has achieved 7 million tons of cargo annually. The excellent geographical location of Małaszewicze has unfortunately reinforced limited international transport with Ukraine through the Zurawica-Medyka station in the transport corridor No. 4 impact zone, which currently results in the increased interest in large logistics companies in the infrastructure of the border area. A terminal capable of handling 100 thousand containers (TEU) per year belonging to a Czech operator has been created. PKP Cargo has bought a plot of 30 hectares in the free customs zone (in Polish: WOC) of Małaszewicze-Terespol in order to create a comprehensive infrastructure that supports transportation in relations with the Far 
East. Talks with Chinese partners allow for hope that Małaszewicze becomes an important part of the so-called Silk Road - a large, strategic Eurasian project supported by the Chinese authorities. Since the nineties, the existence of WOC allows for industrial plants to be located in Małaszewicze-Terespol, bottling of LPG, or the recently expanded facilities in imports of cars and goods vehicles to Belarus and Russia (Brdulak, 1995; Brdulak, Kucharuk, Piekarzewska, 1996; Brdulak, Zakrzewski, 2013).

In recent times, the opening of the Polish economy can be seen, including the transport sector, on the eastern market: Belarus, Russia, Kazakhstan and China. The Chinese have become interested in the Southern Podlasie region due to a well-developed transport infrastructure in the region, with a "wide" railway line adjusted to the dry port railway in Małaszewicze or the unused post-military airport in Biała Podlaska (e.g. in view of the airport cargo). The currently functioning Małaszewicze PKP Cargo SA logistics centre can handle all rail traffic from the Far East. The Polish part can reload 340 containers a day in Małaszewicze and terminal storage capacity is 1900 units after undergoing thorough modernization of the container terminal which was carried out in 2010. Meanwhile, back in the summer of 2015, only 30-40\% reloading capacity of the dry port railway in Małaszewicze was used. In addition, at the same time Małaszewicze can reload three pairs of trains and carry out the loading of goods vehicles, and a plot of approx. 40 hectares is prepared for investment. Another advantage is the fact that a duty free zone has been operating in Małaszewicze for many years, which also does not fully utilize its high potential.

China's interest in the railway line through Terespol is not accidental. This project is interesting in terms of logistics and transport and it is not only on a European scale. A letter of intent was signed on 16 June 2015 in Warsaw between the PKP Cargo group and the Zhengzhou International Hub company of the Chinese province of Henan. The intention was to create a company which would deal with rail container transport between China and Europe. The plan is to expand the "dry" port station in Małaszewicze belonging to PKP Cargo. By using the existing infrastructure, it will be possible to adapt the "port" for handling the increased number of containers from China and to provide additional logistics services such as warehousing and packaging. Thanks to this, Małaszewicze will become a major hub for the transshipment of containers carried by rail between China and Western Europe. The number of trains from China is expected to grow to 25 per month. Therefore, there is a chance to create a real centre of redistribution of loads for the whole of Western Europe in Southern Podlasie.

It should be noted, however, that the currently discussed border region does not meet the multifaceted criteria for the coordinated activities of different companies, some of which have "logistics centre" in their name. Each of the entities run their own business and are not looking for synergy effects in cooperation with other partners in the region. The duty free zone is of international importance but is managed by the weak border municipality of Terespol, which effectively precludes the use the potential of this prime location.

In the further assumption, a logistics centre in Małaszewicze could consist of several elements because of the possibility of coordination of several modes of transport (road, rail, air cargo, pipelines), remote from the management centre, by a few to several kilometers away: ramps and the "dry port" railway infrastructure in Małaszewicze (approx. 6 thousand ha), WOC Małaszewicze-Terespol (166 ha), the road network with access roads to the planned A2 motorway and post-military airports in Biała Podlaska (605 ha) (Zakrzewski, 2007, pp. 12-14; Zakrzewski, 2008, pp. 26-34).

The southern part of the łosicki district along with the town itself and the eastern part of Siedlce is another promising area in creating a logistics centre due to the proximity of the A2 
and S19 intersection of the Pan-European Transport Corridor No. 2. A road-rail centre should be created in the region of Siedlce, which would strengthen the centre in relation to the strong influence of the Warsaw agglomeration. At the same time, it is necessary to strive for greater supra-regional integration and strengthen the functional connections, including logistics in the mentioned area of Lublin, part of Podlasie. This will help to optimize the use of its potential, as well as the economic revival of districts, which includes the peripheral problem in relation to major regional centres and weaknesses of their relationships (e.g. Biała Podlaska in relation to Lublin, and Siedlce to a lesser extent) (Banak, 2011).

\section{ROAD INVESTMENTS IN THE EASTERN PART OF THE PAN-EUROPEAN TRANSPORT CORRIDOR NO. 2 AND TSL COMPETITION FROM BELARUS}

The lack of quality road infrastructure and especially the vague prospects of the construction of the section of the A2 motorway from Warsaw to Terespol is the barrier hindering the development of the logistics infrastructure in the eastern part of Pan-European Transport Corridor No. 2. It is not really known when it will be built in total (it is a prospect of at least 10 years). On 9 October 2015, a tender was announced for the design and construction of the A2 motorway between Warsaw-Kukuryki for the section to the "Lublin" junction from the beginning of the Mińsk Mazowiecki ring road. The proceedings were published under restricted two-stage tendering - in the 1st stage contractors will file requests to participate in the proceedings. The deadline for applications was set for 12 November 2015. Contractor (up to 20) which will be shortlisted for the second stage will be invited to submit a tender where the criterion for evaluation of tenders will not be only the price but also the completion date and guarantee period.

The construction of the A2 motorway in the direction of the east of Warsaw which has been postponed in time, will end the difficulties for drivers of both cars and goods vehicles travelling on the congested national road No. 2. However, this will happen after a period of approximately 10 years. The residents of the suburban villages of Warsaw, who feel the burden of transit traffic, particularly heavy road transport and the continuously resulting noise from it, should feel the improvement. The investment has been divided into two assignment tasks:

1. Task A: "Design and construction of the A2 motorway from Warsaw-Kukuryki to the "Lublin" section junction from the beginning of the Minsk Mazowiecki" ring road section and from "Lublin" junction (without the junction) to the "Konik" junction (including the junction) with a length of about $5.6 \mathrm{~km}$

2. Task B: "Design and construction of the A2 motorway from Warsaw - Kukuryki on the section of the "Lublin" junction to the beginning of the Mińsk Mazowiecki ring road", section II from the "Konik" junction (without the junction) to the beginning of the Minsk Mazowiecki ring road with a length of about $9 \mathrm{~km}$.

It is planned to build $14.6 \mathrm{~km}$ of a dual-carriageway motorway, with a reserve of $11 \mathrm{~m}$ for the construction of the future third lane with the "Konik" junction from the national road No. 2/92 (in task A) with environmental protection and road safety installation in the scope of the project. The anticipated commencement date of investment is being foreseen for December 2016 and completion for the end of April 2020. The reason for such distant deadlines is the fact that the winner of the tender will have to first complete the project and then apply for the necessary permits for construction. After commissioning the new section, drivers will have $40 \mathrm{~km}$ of the A2 motorway east of Warsaw to their disposal. 
Unfortunately, a narrow stretch of road from Kałuszyn to the border will remain, which means that for at least the next few years there will continue to be a 'hole' in the motorway in the heart of Europe. It inhibits the development of entrepreneurship especially in the field of TSL. Meanwhile, there is growing competition from abroad for Polish transport operators in eastern Poland on the international Pan-European Transport Corridor No. 2.

The development of the logistics infrastructure in eastern Poland in the area of Pan-European Transport Corridor No. 2 belt has been inhibited due to the lack of the A2 motorway stretch from Warsaw to Terespol and it is all the more necessary that there is increasing competition in Belarus for Polish transport carriers. The government of Belarus has an earnings plan for European imports from China and capture market movements from Europe to the east mainly to the countries of the Customs Union. In Belarus, customs logistics warehouses are being built along the major road crossings for several years now. Thus, modern logistics centres have been arising on the Belarusian side of the eastern Polish border and not on the Polish side. The first logistics complex in Brest, called the Transport-Logistics centre, was created after an agreement with the local customs authorities in April 2008. The opening took place 20 September 2011. It has an area of 2.3 thousand $\mathrm{km}^{2}$ and has 6 docks for goods vehicles. It is located $6 \mathrm{~km}$ from the Polish border with good access from the M1/E30. There is parking space for 124 goods vehicles and 82 passenger cars nearby (Przybylski, 2015, pp. 36-37).

There are more similar examples. The newest logistics complex in Brest "Biełtamożserwis-2" opened in late 2014 and is located only 800 meters from the Polish border near the Kozłowicze terminal. The three hectare plot contains a warehouse and a bonded warehouse. The total area of the warehouse is $15,000 \mathrm{~m}^{2}$ and it is mechanized, and five layers of pallets can be stored. There is room for 11,028 pallets in the warehouse. There is a warehouse clearance time and cooling chambers for 1008 pallets. There is a hostel for 40 persons and parking for 140 goods vehicles near the warehouse. The road to the terminal is free, but the vehicle must be compulsorily equipped with the BelToll reader system, which can be bought only at the terminal. Without it, the driver will pay a fine of 260 euros. The Belarusian state programme aimed at the TSL businesses, which aims to support traffic to the countries of the Customs Union, is currently at an early stage of development, and the large warehouse in Brest is not being filled (Przybylski, 2015, pp. 36-37).

Cross-border projects are a part of the programme of the Council of Ministers of Belarus, who passed Resolution No. 1249 of 29 August 2008 on the development of the logistics network of the country by 2015. In order to encourage private capital for the construction of logistics centres, the president, Aleksandr Lukashenko, signed a series of decrees in 2009, providing among others for the exemption from taxes. In this document, the Belarusian Government indicates that the logistics systems increase the competitive opportunities not only for businesses but for the whole Belarusian state. In the near future, in the vicinity of Minsk alone, there is to be 13 logistics warehouses, 6 in Brest, 5 in Mogilev, making a total of 36 for Belarus. In 2011, from this list, there were 25 logistic investments and 16 belonging to closed joint-stock companies, under construction. Among them, there were 12 centres (government programme) and 10 private ones being constructed, with 7 in Brest (Przybylski, 2015, pp. 36-37).

Transshipment of goods in Belarus, however, does have its difficulties, because deliveries undergo customs transit procedures. This means that the costs involved are very high, in addition complicated customs and legal formalities arise. In this formal and legal situation, general cargo accounts for a small proportion of goods transported in Belarus and mainstream transport is still based on entire vehicles. Therefore, for logistic operators, it is easier to consolidate loads in Poland and transport them to Belarus, Russia, Kazakhstan and China, than to reload them 
beyond our eastern border. This is an opportunity for the Polish side and the multi-branch CL in Małaszewicze where there has been a duty free zone for many years. Unfortunately, the lack of infrastructure investments in Polish road and rail transport in the eastern part of the Polish section of the Pan-European Transport Corridor No. 2 is a worrying signal which places competition from Belarusian carriers in a privileged position.

\section{CONCLUSIONS}

From the point of view of the logistics environment, logistics networks are formed from interpenetrating various supply chains which hosts the flow of information, raw materials and finished products. Logistics networks have a strong relationship with the transport infrastructure which provides a framework for logistics flows. Logistics networks have hubs where they combine to supply chains, and changing the direction of the flow of goods, handling, separation or combination loads, changing operators, owners of goods, means of transport, etc. all follow. Warehouses logistics operators and distributors, Cross Docking Station platforms, loading terminals, ports, etc. are all hubs. In strategic terms these are especially logistics centres dedicated for logistics operations.

Issues of qualitative transformation of the transport infrastructure in the Pan-European Transport Corridor No. 2 on its Polish section were analyzed in recent years in the macro spatial context (Brdulak, Zakrzewski, 2013, pp. 25-43), as well as on a regional scale, Southern Podlasie in connection with the need to extend the A2 motorway in the direction of the eastern border of the country and the European Union and strengthen the existing border logistics infrastructure (Zakrzewski, 2008, pp. 21-24). It seems appropriate to enrich the analysis of these considerations concerning the location of potential logistics centres (Kuśmińska-Fijałkowska, Łukasik, 2011, pp. 395-400) in the eastern part running through Poland, the second international transport corridor, as well as the analysis as to the functions such logistics centres have to fulfill. From the analysis of material literature and data presented in the article, it appears that:

- the logistics centre remains a structured organizational, legal, technical, economical and spatial accumulation due to the state of transport infrastructure - the social and economic processes of entities that co-contribute in a coordinated manner to meet the complex needs of logistics within specific supply chains;

- we distinguish logistics centres depending on the scope of functions, the scale of impact, supported product, spatial position, branches of operated transport;

- since the accession to the European Union, the eastern part of Poland has been a convenient place for the location of modern logistics centres and lies in the impact zone of Pan-European Transport Corridor No. 2;

- the next establishment of an expanded logistics centre of international importance is the border zone between the town of Biała Podlaska and Małaszewicze-Terespol;

- the lack of A2 motorway section from Warsaw to Terespol is a barrier to the development of logistics infrastructure in eastern Poland in the area of Pan-European Transport Corridor No. 2 belt. In reality, the section from Warsaw to Terespol will be opened in approx. 2027;

- in the meantime, the logistical potential of eastern Poland is being wasted for there is increasing competition on our eastern border - modern logistics centres have been established on the Belarusian side and are ready to receive cargo handling from Russia and China. 


\section{REFERENCES}

Banak, M. (2011). Siedlce i Łosice jako potencjalne centra logistyczne na Mazowszu. Kwartalnik Celny, 2 (13).

Banak, M., Brdulak, J., Krysiuk, C., Pawlak, P. (2014). Kierunki rozwoju infrastruktury transportu samochodowego $w$ Polsce. Warszawa: ITS.

Brdulak, J. (1989). Transport wodny śródlądowy jako element systemu transportowego Polski. Warszawa: SGPiS.

Brdulak, J. (1995). Projekt organizacyjno-ekonomiczny infrastruktury technicznej makroregionu województw bialsko-podlaskiego, chetmskiego, lubelskiego i tarnobrzeskiego. Warszawa: Bizant.

Brdulak, J., Kucharuk, T., Piekarzewska, H. (1996). Niektóre uwarunkowania rozwoju gospodarczego Mazowsza. Warszawa: SGH.

Brdulak, J., Zakrzewski, B. (2008). Ocena ekonomicznej efektywności funkcjonowania centrum logistycznego w Małaszewiczach - założenia teoretyczne. Transport Samochodowy, 4, 26-37.

Brdulak, J., Zakrzewski, B. (2013). Efektywność centrum logistycznego na Południowym Podlasiu. Warszawa: ITS.

Brdulak, J., Zakrzewski, B. (2013). Methods for Calculating the Efficiency of Logistics Centres. Archives of Transport, 27-28 (3-4), 25-43.

Fechner, I., Szyszka, G. (2006). Centra logistyczne jako element integracji regionów. In: B. Liberadzki, L. Mindur (eds.), Uwarunkowania rozwoju systemu transportowego Polski. Warszawa: ITEE.

Kuśmińska-Fijałkowska, A., Łukasik, Z. (2011). The Land Trans-Shipping Terminal In Processes Flow Stream Individuals Intermodal Transportion. TransNav: International Journal on Marine Navigation and Safety of Sea Transportation, 5, 395-400.

Kuśmińska-Fijałkowska, A., Łukasik, Z. (2015). European Establishing a Framework for Maritime Spatial Planning. In: A. Weintrit, T. Neumann (eds.), Information, Communication and Environment. Marine Navigation and Safety of Sea Transportation (pp. 135-138). CRC Press/Balkema.

Kuśmińska-Fijałkowska, A., Łukasik, Z. (2015). Information and Communication Technologies in the Area with a Complex Spatial Structure. In: A. Weintrit, T. Neumann (eds.), Information, Communication and Environment. Marine Navigation and Safety of Sea Transportation (pp. 131-134). CRC Press/ Balkema.

Paprocki, W. (2003). Ekonomiczne aspekty tworzenia i funkcjonowania Centrów Logistycznych. Warszawa: Komitet Transportu PAN.

Przybylski, R. (2015). Białoruska strategia logistyczna. Przewoźnik, 4 (43), 36-37.

Skowron-Grabowska, B. (2010). Centra logistyczne w łańcuchach dostaw. Warszawa: PWE.

Zakrzewski, B. (2007). Międzynarodowe korytarze transportowe w Polsce. Kwartalnik Celny, 2 (2), 12-14.

Zakrzewski, B. (2008). Wizja centrum logistycznego w Małaszewiczach. Kwartalnik Celny, 1 (3), 14-16.

Zakrzewski, B. (2008). Sieć drogowa północnej Lubelszczyzny. Kwartalnik Celny, 3 (5), 21-24.

Zakrzewski, B. (2008). Projekt organizacyjny centrum logistycznego w Małaszewiczach. Biuletyn Informacyjny ITS, 3, 26-34.

\section{Centra logistyczne Polski Wschodniej w II Paneuropejskim Korytarzu Transportowym}

STRESZCZENIE | Przesunięcie granicy celnej Unii Europejskiej na linię Bugu i pojawienie się inwestorów zagranicznych na wschodzie Polski w pasie oddziaływania II Paneuropejskiego Korytarza Transportowego stworzyło w ostatnich latach nowe możliwości rozwojowe. Celem artykułu jest scharakteryzowanie centrów logistycznych i ich potencjału na przykładzie 
Polski wschodniej, w pasie Paneuropejskiego Korytarza Transportowego nr II. Analizę charakteru, funkcjonalności i rodzajów centrum logistycznego zakończono wyprowadzeniem przez autora własnej definicji centrum logistycznego. W artykule opisano inwestycje transportowe we wschodniej części Paneuropejskiego Korytarza Transportowego $\mathrm{nr}$ II oraz wskazano na zagrożenia, np. konkurencję za wschodnią granicą ze strony centrów logistycznych lokalizowanych na Białorusi, które mogą przechwytywać ruch towarowy z Rosji i Chin.

centra logistyczne, współpraca transportowa, integracja europejska, międzynarodowy korytarz transportowy $\mathrm{nr} 2$, infrastruktura transportowa, autostrada A2

Translated by Bartosz Zakrzewski 